NBER WORKING PAPER SERIES

\title{
EVIDENCE THAT SEAT BELTS ARE AS EFFECTIVE AS CHILD SAFETY SEATS IN PREVENTING DEATH FOR CHILDREN AGED TWO AND UP
}

\author{
Steven D. Levitt \\ Working Paper 11591 \\ http://www.nber.org/papers/w11591 \\ NATIONAL BUREAU OF ECONOMIC RESEARCH \\ 1050 Massachusetts Avenue \\ Cambridge, MA 02138 \\ August 2005
}

I would like to thank Gary Becker, Julie Cullen, Stephen Dubner, Paul Heaton, Kevin Murphy, Jesse Shapiro, and Chad Syverson for helpful comments and discussions. Ethan Lieber and Rachel Tay provided outstanding research assistance. This research was funded in part by the National Science Foundation and a research grant from Sherman Shapiro. Mailing address: Department of Economics, University of Chicago, 1126 E. 59th Street, Chicago, IL 60637. email: slevitt@uchicago.edu. The views expressed herein are those of the author(s) and do not necessarily reflect the views of the National Bureau of Economic Research.

(C)2005 by Steven D. Levitt. All rights reserved. Short sections of text, not to exceed two paragraphs, may be quoted without explicit permission provided that full credit, including (C) notice, is given to the source. 
Evidence that Seat Belts are as Effective as Child Safety Seats in Preventing Death for Children Aged Two and Up

Steven D. Levitt

NBER Working Paper No. 11591

August 2005

JEL No. K2, R4

\title{
$\underline{\text { ABSTRACT }}$
}

Over the last thirty years, the use of child safety seats in motor vehicles has increased dramatically, fueled by well publicized information campaigns and legal mandates. In spite of this movement, there is relatively little empirical evidence regarding the efficacy of child safety seats relative to the much cheaper alternative of traditional seat belts. Using data from the Fatality Analysis Reporting System (FARS) on all fatal crashes in the United States from 1975-2003, I find that child safety seats, in actual practice, are no better than seat belts at reducing fatalities among children aged 2-6. This result is robust to a wide range of sensitivity analyses, including controlling for sample selection that arises because the FARS data set includes only crashes in which at least one fatality occurs.

\author{
Steven D. Levitt \\ Department of Economics \\ University of Chicago \\ 1126 E $59^{\text {th }}$ Street \\ Chicago, IL 60637 \\ and NBER \\ slevitt@uchicago.edu
}


The National Highway Transportation Safety Administration (NHTSA) estimates that child safety seats have saved over 6,000 lives between 1975 and 2003, including over 400 in 2003 (Kahane 2004, Starnes 2005). In response to the apparent life-saving benefits of car seats, an expanding set of state and national regulations have been put into place. All 50 states currently require that children ride in approved safety seats. The required ages and weights up to which a child must use a safety seat vary by state, but have been steadily increasing over time (Insurance Institute for Highway Safety 2004). As a consequence, child safety seat usage has increased dramatically. Child safety seats have been heralded as one of the most successful safety innovations of recent decaces (Kahane 1986), with benefit-cost ratio estimates as high as thirty-two to one (Children's Safety Network 1996). According to the 1997 Census of Manufactures, more than four million child car seats were purchased in 1997, with an estimated cost to consumers of more than $\$ 300$ million.

Given the widespread use of child safety seats and the substantial consumer expenditure on them, there is relatively little systematic empirical research evaluating their effectiveness, most of it done by NHTSA researchers (Kahane 1986, Partyka 1988, Hertz 1996). All of these studies find that child safety seats greatly reduce injuries relative to passengers who ride unrestrained. $^{2}$

Often overlooked in the public discussion of the safety of child passengers is the

\footnotetext{
${ }^{2}$ Based on sled tests with crash test dummies and accounting for the mix of correctly and incorrectly used child safety seats in 1984, Kahane (1986) estimates that safety seats reduced both fatalities and hospitalizations by 46 percent relative to children riding unconstrained. Partyka (1988) and Hertz (1996) each use a "double pairs" comparison to evaluate restraint effectiveness. The ratio of driver fatalities to child passenger fatalities in which the child is restrained is compared to the ratio of driver to child passenger deaths when the child is unrestrained. This double pairs analysis does not condition on any additional variables except whether the driver is wearing a seat belt and whether the child is seated in the back seat. Partyka (1988), using data from 1982 to 1987, estimates that child safety seats are 69 percent effective in reducing fatalities of infants and 47 percent effective in reducing fatalities for children aged 1-4. Hertz (1996), using a similar methodology but later data, finds that child safety seats reduce fatalities of infants by 71 percent and 58 percent in cars and light trucks/vans respectively relative to riding unrestrained. For children aged 1-4 the corresponding numbers are 54 and 59 percent.
} 
availability of traditional seat belts as a substitute for child car seats, except for very young children. When NHTSA computes lives saved from child safety seats, for instance, the assumed counterfactual is one in which all children are completely unrestrained. Unlike child car seats, which represent a substantial incremental expense (carrying a typical retail price between $\$ 50$ and \$300), lap and shoulder belts have been standard equipment in the front seat of all passenger vehicles manufactured since 1974. Some form of seat belt - either lap and shoulder belts or just lap belts - are available in the back seats of all recent vehicles. ${ }^{3}$

In previous studies published by NHTSA, the point estimates on seat belts suggest they are less effective than child safety seats (Kahane 1986, Partyka 1988, Hertz 1996). ${ }^{4}$ There are a number of important caveats, however, on this prior research. First, these studies combine cases in which a child uses a lap and shoulder belt with instances of using lap-only belts, which in theory are less beneficial. Second, the estimates include children as young as one year old, for whom seat belts are likely to be especially ill-fitting. Third, no standard errors are reported in these earlier studies. When I replicate their analyses, I cannot reject the null hypothesis of equal coefficients on seat belts and child safety seats due to substantial standard errors. ${ }^{5}$

The raw data from the Fatality Analysis Reporting System (FARS) database covering the universe of fatal motor vehicle crashes in the United States over the period 1975-2003 further calls into question the effectiveness of car seats relative to seat belts when one restricts the

\footnotetext{
${ }^{3}$ Tarbet (2004) estimates that the cost of a seat belt to an automobile manufacturer is roughly $\$ 25$, well below the wholesale cost of a child safety seat. Moreover, existing child safety seats only work using the seat belts installed in the car, so seat belts are a necessary input to child safety seats anyway.

${ }^{4}$ Kahane (1986) found that lap-only seat belts reduced fatalities of children by 33 percent relative to those who were unrestrained, and hospitalizations by 50 percent. Partyka (1988) estimates that seat belts are 36 percent effective in reducing fatalities among children aged 4 and under. Hertz (1996) reports that seat belts are 47 percent effective on children aged 1-4 in passenger cars and 48 percent effective on the same age group in light trucks and vans.

${ }^{5}$ For instance, in replicating Hertz (1996), I obtain bootstrapped standard errors of .06 on the child car seat estimate for 1-4 year olds and .05 on the seat belt estimate for that same age. It is also worth noting that I have been unable to precisely replicate the findings of these earlier papers; in all cases, I obtain slightly smaller gaps between child safety seats and seat belts.
} 
sample to the age groups for which there is substantial overlap in the use of car seats and seat belts (ages 2-6). Table 1 reports injury severity outcomes by type of restraint used for children aged 2-6 riding in passenger vehicles that are involved in accidents with at least one fatality. ${ }^{6}$ Nearly 30 percent of the children who are unrestrained die in these crashes. In comparison, 18.3 percent of children in child safety seats die. The death rate among children using lap and shoulder belts is slightly higher in the raw data, at 19.2 percent. Those using lap belts only, on the other hand, experience slightly lower death rates of 16.7 percent. The other rows of Table 1 , which correspond to lesser injuries, suggest that child safety seats may somewhat outperform seat belts in terms of the types of non-fatal injuries sustained.

There are many reasons why the raw crash data might provide misleading estimates of the causal impact of child safety seat and seat belt usage. First, crash severity, vehicle type, and other circumstances may systematically vary across children using different types of restraints and unrestrained children. Second, there have been substantial technological improvements in both child safety seats and seat belts over the last three decades. A comparison of their average effectiveness over the entire sample may differ substantially from the benefits afforded by the currently available technology. Third, the FARS database includes only crashes in which a fatality occurs. If the use of a child restraint affects the probability a child dies, and there are no other fatalities resulting from the crash, then there is sample selection with respect to which crashes are included in the data (Levitt and Porter 2001).

In this paper, I carry out the most thorough analysis to date of the effectiveness of child safety seats and seat belts in saving children's lives and reducing injury severity in motor vehicle crashes. The analysis controls for a wide range of observable individual, vehicle-level, and crash-

\footnotetext{
${ }^{6}$ Details of the rules used to construct the precise sample used in Table 1 and throughout the paper are described in the data appendix.
} 
level characteristics. Inclusion of these control variables, however, does little to alter the basic conclusion that emerges in the raw data regarding fatalities.

In actual practice, child safety seats do not appear to provide any reduction in fatality risk relative to traditional lap and shoulder seat belts for children aged two and up. ${ }^{7}$ Furthermore, once controls are included, the apparent reduction in injuries when using car seats vis-à-vis seat belts largely disappears. These results are robust to a wide range of sensitivity analyses, including limiting the sample to crashes in recent years, particular types of vehicles and crash impacts, and focusing only on safety restraints which are being properly used according to police reports. The results continue to hold when the sample is restricted to two-car crashes in which someone in the other vehicle dies, which eliminates sample selection bias under quite general assumptions, as demonstrated in Levitt and Porter (2001).

In light of these findings, there appears to be little justification for the legal requirements mandating the use of child safety seats for children aged two and up, as opposed to providing parents the flexibility of using either child safety seats or seat belts. Current annual expenditures on child safety seats for children aged two and up in the United States is in the hundreds of millions of dollars, an investment that appears to provide limited safety benefit. Moreover, because of the current requirements that children be place in safety seats, existing seat belts have not been optimized for use on young children. One could imagine that, absent the existing car seat laws, car manufacturers could equip new vehicles with seatbelts designed to more comfortably and effectively accommodate child passengers at relatively low cost.

A second result of the paper is that the benefits in terms of reduced death and injury of

\footnotetext{
${ }^{7}$ I have also looked at the one-year olds. Because few one-year olds wear adult seat belts, the estimates are quite imprecise. It should be noted, however, that the point estimate on child safety seats is greater than the point estimate on either form of seat belts for one year olds, which is consistent with child safety seats providing better protection for children under the age of two.
} 
moving children from the front seat to the back seat are substantially smaller than the corresponding benefit to adults of moving to the back seat. This finding raises the question of whether the absence of legal rules and public awareness campaigns about the danger of front seats for adults is due to a difference in the relative utility associated with adults riding in the front seat versus the back seat, or a lack of awareness of the risks borne by adult passengers riding in the front seat.

The remainder of the paper is organized as follows. Section I briefly reviews the history and background on child safety seats and seat belts. Section II describes the estimation approach and the data used in the analysis. Section III presents the basic empirical results. Section IV explores whether sample selection in the set of crashes that are included in the data set affects the results. Section V analyzes non-fatal injuries and estimates parallel specifications for adults. Section VI concludes.

\section{Section I: Background on Child Safety Seats}

The concept of the child safety seat was first introduced in the mid 1960s by car manufacturers. ${ }^{8}$ In 1971, NHTSA issued the first federal safety standard addressing child safety seats. Entitled FMVSS 213, it required that safety seats be anchored by the vehicle's seat belts, but did not initially have any requirements regarding performance in crash tests. In 1981, FMVSS 213 was revised to require that the safety seat meet certain requirements in $30 \mathrm{mph}$ crash tests. In 1999, further stipulations related to the distance the head travels in crash tests and requiring safety seats to have upper and lower tethers were added. FMVSS 225, also published in 1999, requires motor vehicles to have anchors for attaching the tethers.

\footnotetext{
${ }^{8}$ The background information on car seats draws heavily on Kahane (1986, 2004) and Insurance Institute for Highway Safety (2005). The interested reader is directed to these sources for greater detail on the subject.
} 
Tennessee was the first state to mandate safety seats for young children in 1978. by 1985, every state in the country had enacted such laws. Over time, the statutory age at which children have been allowed to "graduate" from child safety seats to seat belts has increased. As of 2003, 44 states required children to be in safety seats at least until their fourth birthday. Since that time, more than a dozen states have increased the age or weight requirement, extending the population mandated to ride in safety seats.

The fraction of children in car seats has paralleled the rise of laws requiring their use. Kahane (1996) reports that only 16 percent of children under the age of four were restrained in child safety seats in 1974, but Glassbrenner (2003) finds that by 2002, more than 82 percent of children aged 1-3 were in car seats. ${ }^{9}$

\section{Section II: Data and Estimation Approach}

The data used in this analysis are drawn from the Fatality Analysis Reporting System (FARS) for the period 1975-2003. ${ }^{10}$ FARS contains detailed information on all vehicles and passengers for the universe of motor vehicle crashes in which at least one person dies. Over the period studied, there were more than 1.13 million fatal crashes involving more than 1.67 million vehicles and 2.78 million individuals. Roughly $38 \%$ of the individuals in these crashes died. Included in the FARS data is information on the type of restraint use by each vehicle occupant, which distinguishes between lap-only seat belts, lap and shoulder seat belts, and child safety seats. ${ }^{11}$

\footnotetext{
${ }^{9}$ Glassbrenner (2003) does not distinguish between backless booster seats and seat belts, and thus this estimate understates the true use of car seats and booster seats

${ }^{10}$ FARS is the standard data source for analysis of motor vehicle fatalities. See, for instance, Evans (1986), Saffer and Grossman (1987), Ruhm (1996), Braver et al. (1997), Lave and Elias (1997), Cohen and Dehejia (2004), and Grabowski and Morrisey (2004).

11 There are currently a wide variety of types of child safety seats in use (e.g. rear-facing, forward-facing, backless
} 
I restrict the data set in a number of dimensions. Crashes in which the only fatalities are to pedestrians, motorcyclists, or occupants of non-standard vehicles (e.g. four-wheeled all-terrain vehicles) are dropped from the sample. For the remaining crashes, the sample is limited to occupants of automobiles, mini-vans, and sports-utility vehicles (SUVs) with model years later than 1969. I drop individual records in which injury severity is unknown or missing, as well as cases in which restraint use (i.e. child safety seat, lap belt, lap and shoulder belt, no restraint) is missing. In addition, observations with unknown or missing values for age, gender, the hour of the crash, the principle point of impact, the day of the week, or crashes in which the person was not seated in one of the first three rows of the vehicle were dropped.

The sample covers children aged two to six. Children under the age of two are almost exclusively in child safety seats or unrestrained, and children over the age of six are rarely observed in child safety seats in the data. Thus, only for the age range two to six are direct comparisons of child safety seats and seat belts available. After these exclusions, and limiting the ages in this manner, 37,635 observations remain. ${ }^{12}$

To measure the relationship between restraint use and injury severity, I estimate linear probability models of the form: ${ }^{13}$

$$
\operatorname{InjSev}_{i}=\sum_{r=1}^{R} \beta_{r} * r_{i}+X_{i} \Gamma+\varepsilon_{i}
$$

where $i$ and $r$ index individuals and restraint types respectively. Restraint types $r_{i}$ are mutually

\footnotetext{
booster seats, etc). In addition there are dozens of car seat manufacturers. Unfortunately, the FARS data that we use does not allow us to distinguish the style or brand of car seat in use in a particular vehicle, although the age of the occupant provides a strong signal as to whether the seat is forward or backward facing.

12 Later in the paper, I also estimate parallel specifications for adults in order to compare the relative benefits of seat belts and riding in the back seat for children and adults.

${ }^{13}$ None of the results of the paper are sensitive to using logit or probit models and evaluating the marginal effects at the sample means.
} 
exclusive indicator variables corresponding to no restraint, child safety seat, lap belt only, and lap and shoulder belt. ${ }^{14}$ InjSev is one of a series of indicator variables reflecting the injuries sustained in the crash. My focus is primarily on fatal injuries, but results are also reported for varying degrees of non-fatal injury severity. A wide variety of characteristics corresponding to the individual, the vehicle he or she is traveling in, and the particulars of the crash are included in the vector of covariates $X$. There are individual-level controls for the seat position (i.e. front seat, back right, back center, back left, and back unspecified), age, and gender. Vehicle characteristics include the model year of the vehicle, whether it is an automobile, minivan, or SUV, the weight of the vehicle, the primary point of the crash impact on the vehicle, whether the driver of the vehicle was wearing a seat belt, and information on the driver's prior moving violations. Crash characteristics capture the number of vehicles in the crash, the total number of occupants in all vehicles in the crash, urban versus rural, time of day, weekday versus weekend, the posted speed limit, and the year of the crash. In two car crashes, we also control for the weight differential of the vehicles in the crash.

Summary statistics for the variables included in the analysis are presented in Table 2. Means and standard deviations for the full sample are shown in the first two columns. The remaining four columns divide the sample by restraint type. More than half of the children in the sample are unrestrained. The remainder of children are distributed relatively equally across child safety seats and the two types of seat belts. Over time, these proportions have shifted away from being unrestrained and toward child safety seats. Direct frontal crashes are the most common. Children who are unrestrained are over represented in vehicles with drivers who are unbelted and

\footnotetext{
${ }^{14}$ There are a small number of observations recorded as shoulder belt only. These are included in the lap belt only category. Following earlier work (Hertz 1996), I code passengers as using a restraint even if they are recorded as using that restraint improperly (for example, a child is in a car seat but not properly buckled, or a single seat belt is used for multiple passengers). In the sensitivity analysis, I also report results excluding individuals who are not using the safety restraints properly. The basic findings are unchanged.
} 
have previous moving violations, in one-car crashes, and in early morning crashes (i.e. between midnight to 6 a.m.). There are few systematic differences in characteristics across the three types of restraints, except that front-seat passengers and earlier model vehicles are more likely to use lap and shoulder belts to restrain children.

\section{Section III: Empirical results}

Table 3 presents regression estimates of equation (1) on the full sample of crashes. The unit of observation is a child-crash. The dependent variable is an indicator equal to one if the child dies and zero otherwise. The estimates reported are from linear probability models. Standard errors are in parentheses. In all specifications, the estimates of restraint effectiveness are relative to a child who is unrestrained, i.e. the omitted category for restraint type is "no restraint used.”

In column 1 of Table 3, the only right-hand-side variables included are the type of restraint used. In this case, the constant term, which is equal to 0.293 reflects the baseline death rate among unrestrained children. Each of the three restraint types (child safety seats, lap and shoulder belts, and lap belts only) provide similar fatality reductions, reducing the death rate between 0.10 and 0.126 , or a little more than one-third of the rate for a child with no restraint. ${ }^{15}$ In each case, the life-saving benefits of the restraints are highly statistically significant relative to the baseline of no restraint use. The null hypothesis of equality across the coefficients of the three restraint types, however, cannot be rejected.

\footnotetext{
${ }^{15}$ The percentage reduction in fatalities reported here is smaller than that estimated in prior research using the paired comparison approach of Partyka (1988) and Hertz (1996). The lower safety restraint effectiveness, when expressed in percentage terms, is likely an artifact of sample selection which leads one to understate the true effectiveness of life saving devices when using the FARS sample (Levitt and Porter 2001). When I control for sample selection in Table 5 of this paper, the effectiveness of the restraints, measured by the percentage reduction in deaths relative to unrestrained passengers, rises to levels comparable to the prior research.
} 
As one moves from left to right in Table 3, progressively more controls are added to the specification. Column 2 includes seating position and age dummies. Adding these controls makes the estimates across the three restraint types even more closely bunched. The back seat is safer than the front seat with the middle of the back seat better than the sides. In side-impact crashes, the child seated near the point of impact fares especially badly; by being in the middle a passenger avoids the direct impacts on either side and is likely to make contact with the front seat.

Column 3 of Table 3 adds indicator variables for the year of the crash, the model year of the vehicle the passenger is traveling in, and the point of impact for the crash. The coefficients on the safety restraints are not greatly affected. Lap and shoulder belts have the largest point estimate, but equality of the three safety restraints cannot be rejected. Column 4 adds a wide array of further controls such as the gender of the child, information about the driver and the vehicle, and the circumstances of the crash (only some of which are included in the table; full results are available from the author on request). Children fare worse in cars and better in heavier vehicles. The impact of restraints remains similar across the three types of devices.

Column 5 of Table 3 includes indicator variables for the number of people involved in the crash. Although it is unlikely that the number of people in the crash has any actual causal link to the probability of death, because of sample selection in how the data set is created, the number of people in the crash serves as an indirect measure of crash severity. Controlling for other factors, the more people in the crash, the more likely that the crash is included in the sample even if this particular child survives. Thus, on average, death rates in observed crashes are strongly negatively related to the number of individuals involved in the crash. ${ }^{16}$ To the

\footnotetext{
${ }^{16}$ Although not shown in tabular form, the coefficients from column 5 of Table 3 imply, for instance, that all else equal the child is 20 percentage points more likely to die in a crash with thee people involved than in a crash with
} 
extent that restraint use is systematically correlated with the number of people in crashes (e.g. if families with more children in the car are less likely to use car seats), failure to control for number of vehicle occupants would lead to biased estimates of the impact of restraint use. Child safety seats and lap and shoulder belts carry identical coefficients; lap-only belts have a smaller point estimate. I am able to reject the null that the lap-only coefficient is equal to the values on the other restraints at the .05 level. ${ }^{17}$

Table 4 further explores the robustness of the estimates on the restraint types to a wide range of crash circumstances, vehicle and passenger characteristics, and alternative data definitions. Each row of Table 4 represents a different regression estimate. The first column of the table presents the mean death rate for unrestrained passengers in that sample. Columns 2-4 show the coefficients on the three restraint types. In all cases, the estimates reported are from specifications including the most extensive set of controls (i.e., corresponding to column 5 of Table 3). Only the coefficients on the restraints are reported in the table.

The first row reports baseline estimates from the overall sample. Each of the subsequent rows corresponds to a different sub-sample of the data. Of the 32 sensitivity analyses I report, the null hypothesis of equality across the three restraint types can be rejected 12 times, largely because of smaller coefficients on lap-only seat belts. The point estimate on child safety seats is more negative than the coefficient on lap and shoulder belts in only 15 of the 32 cases, and in none of the cases can equality of these two coefficients be rejected. In sum, there is no evidence in the data to suggest that child safety seats outperform lap and shoulder belts in this sample.

\footnotetext{
ten people involved.

${ }^{17}$ It is also possible to include vehicle-fixed effects, so that the coefficients are identified solely off of variation from multiple children riding in the same vehicle and involved in the same crash. Because there is relatively little withinvehicle variation in restraint use, however, the estimates become imprecise. The point estimate on child safety seats, lap and shoulder belts, and lap-only belts with vehicle fixed-effects are respectively -.215 (se=.025), -.192 (se=.026), and -.193 (se=.025). One cannot reject the null hypothesis of equality across these three coefficients.
} 
Section IV: Controlling for sample selection in the crashes that are included in the FARS data set

As noted earlier, in order for a crash to be included in the FARS data set, there must be at least one fatality. For those crashes in which a child is the only fatality, if that child would have survived the crash had he or she been differently restrained, the crash would have been absent from FARS. Similarly, for crashes in which no one dies, but a child would have died had he or she been using a different restraint, the sample composition depends upon the child's restraint use. As demonstrated by Levitt and Porter (2001), this sample selection is likely to cause the benefits of effective safety devices to be systematically understated in the analysis presented above. Intuitively, all of the failures of these safety devices are included in the FARS data (since all fatalities are in the data set), but some of the successes are omitted when the safety device works for the passenger in question and no one else dies. For instance, Levitt and Porter (2001) estimate that the actual safety benefits of seat belts for adult front-seat passengers are roughly 25 percent greater than implied by the naïve OLS estimates.

In this paper, I adopt the same strategy for dealing with sample selection used by Levitt and Porter (2001). Namely, I restrict the sample to individuals involved in two-car crashes in which someone dies in the other vehicle. Under the assumption that, conditional on other factors, safety device usage in one vehicle is independent of the fatality outcome of individuals in the other vehicle involved in a crash, limiting the sample in this way eliminates the sample selection problem. ${ }^{18}$ By limiting attention to crashes in which someone dies in the other car, the

\footnotetext{
${ }^{18}$ Note that in order for the estimate to reflect a true causal impact of restraint use, one also requires the standard identifying assumption that, conditional on the set of observed individual and crash characteristics, restraint use is as good as randomly assigned. The presence of a Peltzman (1975) effect, in which the safety afforded by restraint usage leads to more aggressive driving, could lead to bias in the basic specifications, which do not control for restraint use by passengers in the other vehicle. If I do condition on restraint use in the other vehicle, the Peltzman effect is no longer a concern. Empirically, when I control for seat belt use by the driver in the other vehicle, the key results are unaffected.
} 
link between one's own safety device usage and inclusion in the sample is eliminated.

Regardless of one's personal outcome, the crash will be included in the data set.

One important caveat of this approach is that the subset of crashes in which someone in the other vehicle dies may have a distribution of crash severity that is very different from the full universe of crashes. Indeed, crashes in which someone dies in one vehicle appear to be less severe on average for occupants of the other vehicle (e.g. due to differences in vehicle weight, or in the points of impact). It is uncertain whether our estimates from the sample selectioncorrected data generalize to the full distribution of crashes.

Table 5 reports results for the sample selection corrected data that otherwise exactly mirrors the basic regressions in Table 3. The magnitude of the coefficients on the safety restraints are in all cases smaller than in Table 3. This is due to the fact that these crashes are, on average, less severe than the overall sample of crashes. In terms of the percentage of lives saved through the use of safety devices relative to a baseline of no restraint, however, the estimates in Table 5 are larger. The death rate among unrestrained children in this set of crashes is roughly 10 percent. Thus, restraint use cuts fatalities between 44 and 67 percent, depending on the restraint and the specification. As was the case earlier, there is no evidence that child safety seats systematically outperform lap and shoulder belts with respect to preventing fatalities, and only mixed evidence that these two types of devices outperform lap-only seat belts. In none of the six specifications shown can the null hypothesis of equal coefficients be rejected.

Although not shown in tabular form, I have also estimated all of the sensitivity tests included in Table 4, but controlling for sample selection, and for none of the cases can I reject equality of the coefficients on the three restraint types at the .05 level. 
Section V: Non-fatal injuries and a comparison to adult passengers

The focus thus far in the paper has been on fatalities. Restraint systems also affect nonfatal injuries. In the raw data shown in Table 1, it appeared that injury rates may be lower for children in child safety seats relative to seat belts. Table 6 reports regression analysis of injuries. FARS classifies injuries according to five mutually exclusive degrees of severity: fatal, incapacitating injury, non-incapacitating injury, possible injury, and no injury. In the top panel of Table 6, each row corresponds to a specification identical to those presented in column 5 of Table 4, but with the dependent variable an indicator as to whether the listed injury occurred. The first row simply replicates the results for fatalities. The second through fifth rows examine the different degrees of non-fatal injuries. The point estimate on reductions in incapacitating injuries is largest for child safety seats, but I cannot reject equality across the three restraint types. Child safety seats yield the largest number of children with no injuries, by about 1.6 percentage points relative to lap and shoulder belts and 3.6 percent relative to lap-only seat belts. The difference in rates at which no injury occurs is borderline statistically significant when comparing child safety seats and lap and shoulder belts, and significant at the .01 level when comparing child safety seats to lap only seat belts.

The bottom panel of Table 6 is identical to the top panel, except that the results presented correct for sample selection using crashes in which someone in the other vehicle dies. The point estimates suggest a slight shifting by child safety seats away from the more severe non-fatal injuries, relative to lap and shoulder belts, although these differences are not statistically significant. Lap-only seat belts continue to under-perform the other safety restraints with respect to injuries. ${ }^{19}$

\footnotetext{
${ }^{19}$ The findings in Table 6 are largely consistent with the recent work of Doyle and Levitt (2005) that analyzes three different data sets (all crashes reported to the police in New Jersey and Wisconsin, and a nationally represent sample
} 


\section{Analyzing adult outcomes}

Although the focus of this paper is on child outcomes, a comparison to adults yields some additional insights. Table 7 presents results side-by-side for children and adults aged 16 and up for the specifications with the full set of controls. The first two columns do not control for sample selection; the final two columns do. Only the coefficients on safety restraints and seat position are shown in tabular form.

Three points of interest emerge from a comparison of child and adult outcomes. First, the fatality reduction associated with restraint use by adults is roughly double the magnitude for children. This is due in part to the fact that adults are more likely to ride in the front seat than children, and seat belts afford greater benefits to front-seat occupants (as observed in Table 4 for children). Adults also have higher base rates for fatalities in crashes when unrestrained. A second finding is that for adults there is a greater gain in protection afforded by lap and shoulder belts relative to lap belts alone than was observed for children. For instance, in the regressions correcting for sample selection, for children the difference in the coefficients for lap and shoulder belts versus lap only seatbelts is a statistically insignificant 0.006 , whereas for adults the difference is 0.029 , and highly statistically significant. Presumably, the extra benefit of the shoulder harness to adults arises because they are taller and thus more likely to hit their head than children absent a shoulder belt. Finally, it is worth noting that the reduction in fatalities from moving an adult from the front seat to the back seat is higher than that of moving a child to

of crashes reported to the police). Doyle and Levitt find no systematic difference in incapacitating and nonincapacitating injuries for child safety seats and lap and shoulder belts. Child safety seats reduce possible injuries by approximately 20 percent in their sample. These results stand in stark contrast to the results of Winston et al. (2000) and Durbin et al. (2003), both of which draw subjects from insurance claims and conduct telephone interviews to assess restraint use and injury severity, finding that child safety seats reduce injuries by roughly 60 percent relative to seat belts. 
the back seat. ${ }^{20}$ For instance, in the sample selection corrected regression, the difference between the front-seat coefficient and the average of the back left and back right coefficients is 0.012 for children and 0.046 for adults. ${ }^{21}$ From the perspective of minimizing total lives lost, it is optimal to have both adult and child passengers ride in the back seat. But conditional on having one passenger ride in the front seat, from a safety perspective alone, it is better to put the child in front and the adult in back. Although beyond the scope of this paper, it is interesting to note that there has been such an effective public health campaign to move children from the front seat to the back seat, but no parallel effort whatsoever with respect to adult passengers.

\section{Section VI: Conclusion}

Over the past three decades, there has been a concerted public campaign to ensure that all children riding in motor vehicles use child safety seats. The empirical evidence presented in this paper, however, suggests that for children aged two and up, child safety seats provide no discernible advantage over traditional lap and shoulder belts, and only a marginal improvement relative to lap-only seat belts in preventing fatalities. These conclusions are robust to the inclusion of a wide array of covariates, analyzing a variety of sub-samples of the data, including vehicle fixed-effects, and correcting for sample selection in the way the FARS data set is constructed. An obvious question to ask, although one which is beyond the scope of the FARS data, is the extent to which the failure of child safety seats to outperform seat belts is a consequence of child safety seats frequently being improperly installed. Indeed, NHTSA (1996)

\footnotetext{
${ }^{20}$ Presumably the back seat is especially beneficial to adults because they are taller and thus more likely to make contact with the windshield than a child when seated in the front seat.

${ }^{21}$ In the specifications that do not correct for sample selection, the estimated benefit of moving from the front seat to the average of the back left and back right seats is 0.048 for children and 0.073 for adults.
} 
estimates that more than 80 percent of all child safety seats are incorrectly installed. ${ }^{22} \quad$ Based $^{2}$ on crash tests, Kahane (1986) argues that properly installed car seats reduce fatailities by 71 percent, compared to 44 percent for improperly installed safety seats. Thus, there may be potential gains to achieving better installation. On the other hand, it is worth noting that when I conducted my own crash tests at an independent lab using lap and shoulder belts on dummies corresponding to children aged 3 and 6, the seat belts performed well within the guidelines the federal government has established for child safety seats, and just about as well as the (properly installed) child safety seats that I tested. While far from definitive, the crash tests I conducted suggest that even with proper installation, there may not be clear advantages of car seats over seat belts. $^{23}$

The limited apparent effectiveness of child safety seats calls into question the justification for the current legal requirement in all 50 states that children aged two and older be restrained in child safety seats when riding in motor vehicles. Annual expenditures on child safety seats for children two and older are perhaps \$200 million in the United States, an outlay that appears to be providing little return in terms of safety. Indeed, in the long run, the emphasis on child safety seats over seat belts may actually be having a negative impact on child welfare. Because the government mandates the use of child safety seats, there is little financial incentive on the part of automobile manufacturers to invest in developing seat belts that better serve the needs of child passengers.

\footnotetext{
${ }^{22}$ The complexity of correctly installing car seats is underscored by the fact that law enforcement officers undergo a four-day training program to become a certified Child Passenger Safety Technician.

${ }^{23}$ For a longer description of these crash tests, see Dubner and Levitt (2005).
} 
Table 1: Distribution of Injury Severity by Restraint Status

\begin{tabular}{|c|c|c|c|c|}
\hline & No Restraint & $\begin{array}{c}\text { Child Safety } \\
\text { Seat }\end{array}$ & $\begin{array}{c}\text { Lap and } \\
\text { Shoulder } \\
\text { Belt }\end{array}$ & $\begin{array}{c}\text { Lap-Only } \\
\text { Belt }\end{array}$ \\
\hline Fatal & 29.34 & 18.16 & 19.39 & 16.71 \\
\hline Incapacitating & 31.41 & 19.62 & 21.57 & 23.88 \\
\hline Non-Incapacitating & 21.99 & 23.56 & 24.44 & 25.76 \\
\hline Possible Injury & 8.9 & 16.25 & 15.3 & 14.79 \\
\hline No Injury & 8.37 & 22.41 & 19.31 & 18.86 \\
\hline Total & 100 & 100 & 100 & 100 \\
\hline Number of Observations & 21,136 & 6,835 & 5,045 & 4,619 \\
\hline
\end{tabular}

Notes: Entries in the table show the distribution of injury severity by type of restraint system used for children aged 2-6 who were involved in crashes in which at least one person was fatally injured. The data are from the FARS dataset for the years 1975 2003. The total number of observations is 37,365 . See appendix for precise rules regarding construction of the sample. 
Table 2: Sample Statistics

\begin{tabular}{|c|c|c|c|c|c|c|}
\hline & \multicolumn{2}{|c|}{ Full sample } & \multicolumn{4}{|c|}{ Mean by restraint type } \\
\hline & mean & sd & No Restraint & Child Seat & $\begin{array}{l}\text { Lap and } \\
\text { Shoulder } \\
\text { Belt }\end{array}$ & $\begin{array}{l}\text { Lap-Only } \\
\text { Belt }\end{array}$ \\
\hline Child Died & 0.244 & 0.430 & 0.293 & 0.182 & 0.194 & 0.167 \\
\hline \multicolumn{7}{|l|}{ Restraint: } \\
\hline None & 0.562 & 0.496 & 1 & 0 & 0 & 0 \\
\hline Child Seat & 0.182 & 0.386 & 0 & 1 & 0 & 0 \\
\hline Lap and Shoulder Belt & 0.134 & 0.341 & 0 & 0 & 1 & 0 \\
\hline Lap-Only Belt & 0.123 & 0.328 & 0 & 0 & 0 & 1 \\
\hline \multicolumn{7}{|l|}{ Point of Impact: } \\
\hline Direct Front & 0.415 & 0.493 & 0.374 & 0.468 & 0.453 & 0.479 \\
\hline Partial Front & 0.169 & 0.375 & 0.178 & 0.150 & 0.165 & 0.162 \\
\hline Direct Rear & 0.041 & 0.199 & 0.037 & 0.051 & 0.047 & 0.039 \\
\hline Partial Reat & 0.053 & 0.225 & 0.051 & 0.059 & 0.064 & 0.047 \\
\hline Right Side & 0.103 & 0.305 & 0.111 & 0.090 & 0.094 & 0.100 \\
\hline Left Side & 0.083 & 0.276 & 0.083 & 0.085 & 0.078 & 0.087 \\
\hline Non-Collision & 0.086 & 0.280 & 0.108 & 0.057 & 0.059 & 0.056 \\
\hline \multicolumn{7}{|l|}{ Person Seated in: } \\
\hline Front & 0.321 & 0.467 & 0.370 & 0.159 & 0.461 & 0.187 \\
\hline Back Left (Driver's Side) & 0.239 & 0.426 & 0.200 & 0.325 & 0.259 & 0.268 \\
\hline Back Middle & 0.176 & 0.381 & 0.199 & 0.171 & 0.009 & 0.258 \\
\hline Back Right & 0.238 & 0.426 & 0.193 & 0.335 & 0.266 & 0.268 \\
\hline Back Other & 0.027 & 0.161 & 0.039 & 0.010 & 0.005 & 0.018 \\
\hline Male & 0.509 & 0.500 & 0.506 & 0.512 & 0.513 & 0.519 \\
\hline Driver Belted & 0.495 & 0.500 & 0.258 & 0.746 & 0.800 & 0.871 \\
\hline Car & 0.774 & 0.418 & 0.852 & 0.660 & 0.737 & 0.637 \\
\hline One Car Crash & 0.260 & 0.438 & 0.316 & 0.192 & 0.184 & 0.185 \\
\hline Two Car Crash & 0.572 & 0.495 & 0.549 & 0.593 & 0.609 & 0.602 \\
\hline Model Year $\leq 1990$ & 0.705 & 0.456 & 0.846 & 0.476 & 0.704 & 0.422 \\
\hline Model Year > 1990 & 0.295 & 0.456 & 0.154 & 0.524 & 0.296 & 0.578 \\
\hline Minor Moving Violation in Past & 0.170 & 0.376 & 0.192 & 0.133 & 0.158 & 0.139 \\
\hline Major Moving Violation in Past & 0.122 & 0.327 & 0.142 & 0.091 & 0.103 & 0.098 \\
\hline Speed Limit Less than 55 & 0.834 & 0.372 & 0.854 & 0.797 & 0.834 & 0.804 \\
\hline Rural Road & 0.538 & 0.499 & 0.469 & 0.636 & 0.621 & 0.614 \\
\hline Daytime & 0.782 & 0.413 & 0.747 & 0.830 & 0.813 & 0.837 \\
\hline Evening & 0.152 & 0.359 & 0.169 & 0.125 & 0.145 & 0.123 \\
\hline Early morning & 0.066 & 0.248 & 0.084 & 0.045 & 0.042 & 0.039 \\
\hline Weekend & 0.378 & 0.485 & 0.388 & 0.354 & 0.384 & 0.363 \\
\hline Vehicle Weight (1000's Ibs) & 3.020 & 0.779 & 3.025 & 3.048 & 2.950 & 3.026 \\
\hline $\begin{array}{l}\text { Difference in Vehicles' Weights in } \\
\text { Crash }\end{array}$ & 0.578 & 1.004 & 0.521 & 0.639 & 0.608 & 0.719 \\
\hline Number of Occupants in Crash & 5.462 & 2.069 & 5.520 & 5.203 & 5.877 & 5.193 \\
\hline
\end{tabular}

Notes: Summary statistics are for children aged 2-6 involved in crashes in which at least one fatality occurred, as reported in the FARS data for the years 1975 - 2003. Observations with missing values for injury severity, restraint use, seat position, age, sex, or model year were dropped. Additional observations where the restraint was a helmet, the model year of the automobile was before 1970, or the type of automobile was classified as a large truck, non-motorist, motocyclist, or other nonstandard vehicle were dropped. See appendix for precise rules for inclusion in the sample. 
Table 3: Impact of Child Restraints on Probability of Fatality

\begin{tabular}{|c|c|c|c|c|c|}
\hline & \multicolumn{5}{|c|}{ Dependent Variable $=1$ if Fatal Injury, 0 Otherwise } \\
\hline & (1) & $(2)$ & $(3)$ & $(4)$ & $(5)$ \\
\hline \multirow[t]{2}{*}{ Child Seat } & -0.112 & -0.107 & -0.115 & -0.098 & -0.132 \\
\hline & {$[0.006]^{* *}$} & {$[0.006]^{* *}$} & {$[0.007]^{\star *}$} & {$[0.007]^{\star *}$} & {$[0.007]^{\star *}$} \\
\hline \multirow[t]{2}{*}{ Lap And Shoulder Belt } & -0.1 & -0.113 & -0.124 & -0.111 & -0.132 \\
\hline & {$[0.007]^{\star *}$} & {$[0.007]^{* *}$} & {$[0.007]^{\star *}$} & {$[0.008]^{* *}$} & {$[0.008]^{\star *}$} \\
\hline \multirow[t]{2}{*}{ Lap-Only Belt } & -0.126 & -0.106 & -0.112 & -0.098 & -0.108 \\
\hline & {$[0.007]^{* *}$} & {$[0.007]^{\star \star}$} & {$[0.007]^{\star \star}$} & {$[0.007]^{\star *}$} & {$[0.007]^{\star *}$} \\
\hline \multicolumn{6}{|l|}{ Child Seated In: } \\
\hline \multirow[t]{2}{*}{ Front } & & 0.136 & 0.146 & 0.148 & 0.091 \\
\hline & & {$[0.007]^{\star *}$} & {$[0.007]^{\star *}$} & {$[0.007]^{\star *}$} & {$[0.007]^{* *}$} \\
\hline \multirow[t]{2}{*}{ Back Left } & & 0.056 & 0.056 & 0.054 & 0.047 \\
\hline & & {$[0.007]^{\star \star}$} & {$[0.007]^{\star \star}$} & {$[0.007]^{\star *}$} & {$[0.007]^{\star *}$} \\
\hline \multirow[t]{2}{*}{ Back Middle } & & 0 & 0 & 0 & 0 \\
\hline & & {$[0.000]$} & {$[0.000]$} & {$[0.000]$} & {$[0.000]$} \\
\hline \multirow[t]{2}{*}{ Back Right } & & 0.055 & 0.054 & 0.049 & 0.039 \\
\hline & & {$[0.007]^{\star *}$} & {$[0.007]^{\star *}$} & {$[0.007]^{\star *}$} & {$[0.007]^{\star *}$} \\
\hline \multirow[t]{2}{*}{ Other Back } & & 0.034 & 0.024 & 0.017 & 0.027 \\
\hline & & {$[0.014]^{*}$} & {$[0.014]$} & {$[0.014]$} & [0.014] \\
\hline \multirow[t]{2}{*}{ Male } & & & & 0.001 & -0.001 \\
\hline & & & & {$[0.004]$} & [0.004] \\
\hline \multirow[t]{2}{*}{ Driver Belted } & & & & 0.011 & 0.021 \\
\hline & & & & {$[0.006]^{*}$} & {$[0.006]^{\star *}$} \\
\hline \multirow[t]{2}{*}{ Car } & & & & 0.048 & 0.039 \\
\hline & & & & {$[0.007]^{* *}$} & {$[0.007]^{\star *}$} \\
\hline \multirow[t]{2}{*}{1 Car Accident } & & & & 0.128 & 0.002 \\
\hline & & & & {$[0.008]^{* *}$} & [0.009] \\
\hline \multirow[t]{2}{*}{2 Car Accident } & & & & 0.083 & 0.038 \\
\hline & & & & {$[0.007]^{\star *}$} & {$[0.007]^{\star *}$} \\
\hline \multirow[t]{2}{*}{ Car Weight (In 1000s of pounds) } & & & & -0.039 & -0.031 \\
\hline & & & & {$[0.003]^{\star *}$} & {$[0.003]^{* *}$} \\
\hline $\begin{array}{l}\text { Controls included in regression, but not } \\
\text { shown in table }\end{array}$ & & $\begin{array}{l}\text { age of } \\
\text { passenger }\end{array}$ & $\begin{array}{l}\text { year, model } \\
\text { year, age of } \\
\text { passenger, } \\
\text { impact }\end{array}$ & $\begin{array}{l}\text { year, model } \\
\text { year, age of } \\
\text { passenger, } \\
\text { impact, other } \\
\text { controls }\end{array}$ & $\begin{array}{l}\text { year, model } \\
\text { year, age of } \\
\text { passenger, } \\
\text { impact, } \\
\text { number in } \\
\text { crash, other } \\
\text { controls }\end{array}$ \\
\hline \multirow[t]{2}{*}{ Constant } & 0.293 & 0.205 & 0.228 & 0.27 & 0.98 \\
\hline & {$[0.003]^{* *}$} & {$[0.007]^{* *}$} & {$[0.026]^{\star *}$} & {$[0.049]^{* *}$} & {$[0.085]^{* *}$} \\
\hline Observations & 37635 & 37635 & 37635 & 37635 & 37635 \\
\hline R-Squared & 0.02 & 0.03 & 0.06 & 0.08 & 0.11 \\
\hline
\end{tabular}


Notes for Table 3: Dependent variable is an indicator equal to one if the child dies in the crash. The omitted restraint category is "no restraint." Coefficients are from linear probability models, with standard errors in parentheses. The data are from the Fatality Analysis Reporting System (FARS) for the years 1975-2003. See appendix for precise rules for inclusion in the sample. Other controls included in columns 4 and 5 but not reported in the table are the difference in the weight of the cars in a two car crash, if the weight of the vehicle was missing, if the driver had had a major violation in the past, if the driver had had a minor violation in the past, if the speed limit on the road was less than or equal to $55 \mathrm{mph}$, if it was a rural road, if it was a weekend, and three dummies dividing the day into daytime (6 AM to 7 PM), evening (8 PM to midnight), and early morning (1AM to 5AM). The restraint type variables--child seat, lap and shoulder belt, and lap or shoulder belt--are relative to no restraint use. The seating position variables, such as front or back left, are relative to the middle seat in the back. 
Table 4: Sensitivity Analysis

\begin{tabular}{|c|c|c|c|c|c|c|c|c|c|}
\hline Sub-sample & $\begin{array}{c}\text { No } \\
\text { Restraint }\end{array}$ & Child Seat & $\begin{array}{c}\text { Lap and } \\
\text { Shoulder Belt }\end{array}$ & $\begin{array}{l}\text { Lap-Only } \\
\text { Belt }\end{array}$ & Sub-sample & $\begin{array}{c}\text { No } \\
\text { Restraint }\end{array}$ & Child Seat & $\begin{array}{c}\text { Lap and } \\
\text { Shoulder Belt }\end{array}$ & $\begin{array}{l}\text { Lap-Only } \\
\text { Belt }\end{array}$ \\
\hline & (1) & (2) & (3) & $(4)$ & & (5) & (6) & $(7)$ & (8) \\
\hline Baseline & 0.293 & $\begin{array}{c}-0.132 \\
{[0.007]^{* *}}\end{array}$ & $\begin{array}{c}-0.132 \\
{[0.008]^{\star *}}\end{array}$ & $\begin{array}{c}-0.108 \\
{[0.007]^{\star *}}\end{array}$ & $\begin{array}{l}\text { Speed Limit > } 55 \\
\text { mph }\end{array}$ & 0.240 & $\begin{array}{c}-0.133 \\
{[0.017]^{\star *}}\end{array}$ & $\begin{array}{c}-0.143 \\
{[0.018]^{\star *}}\end{array}$ & $\begin{array}{c}-0.156 \\
{[0.018]^{* *}}\end{array}$ \\
\hline Front Seat & 0.318 & $\begin{array}{c}-0.175 \\
{[0.016]^{\star *}}\end{array}$ & $\begin{array}{c}-0.158 \\
{[0.013]^{\star \star}}\end{array}$ & $\begin{array}{c}-0.12 \\
{[0.017]^{\star *}}\end{array}$ & One Car Crash & 0.316 & $\begin{array}{c}-0.181 \\
{[0.016]^{\star *}}\end{array}$ & $\begin{array}{c}-0.171 \\
{[0.017]^{\star *}}\end{array}$ & $\begin{array}{c}-0.165 \\
{[0.017]^{\star *}}\end{array}$ \\
\hline Back Seat & 0.207 & $\begin{array}{c}-0.12 \\
{[0.008]^{\star *}}\end{array}$ & $\begin{array}{c}-0.125 \\
{[0.010]^{\star \star}}\end{array}$ & $\begin{array}{c}-0.101 \\
{[0.008]^{\star \star}}\end{array}$ & Two Car Crash & 0.232 & $\begin{array}{c}-0.112 \\
{[0.008]^{\star \star}}\end{array}$ & $\begin{array}{c}-0.117 \\
{[0.008]^{\star \star}}\end{array}$ & $\begin{array}{c}-0.085 \\
{[0.008]^{\star *}}\end{array}$ \\
\hline Frontal Impact & 0.175 & $\begin{array}{c}-0.126 \\
{[0.010]^{\star *}}\end{array}$ & $\begin{array}{c}-0.118 \\
{[0.010]^{\star *}}\end{array}$ & $\begin{array}{c}-0.076 \\
{[0.010]^{\star *}}\end{array}$ & Daytime & 0.241 & $\begin{array}{c}-0.135 \\
{[0.008]^{* *}}\end{array}$ & $\begin{array}{c}-0.131 \\
{[0.008]^{\star *}}\end{array}$ & $\begin{array}{c}-0.103 \\
{[0.008]^{\star *}}\end{array}$ \\
\hline Partial Frontal Impact & 0.226 & $\begin{array}{c}-0.124 \\
{[0.017]^{\star *}}\end{array}$ & $\begin{array}{c}-0.155 \\
{[0.019]^{\star \star}}\end{array}$ & $\begin{array}{c}-0.122 \\
{[0.018]^{\star *}}\end{array}$ & Evening & 0.243 & $\begin{array}{c}-0.121 \\
{[0.019]^{\star \star}}\end{array}$ & $\begin{array}{c}-0.146 \\
{[0.021]^{\star *}}\end{array}$ & $\begin{array}{c}-0.135 \\
{[0.019]^{\star *}}\end{array}$ \\
\hline Side Impact & 0.339 & $\begin{array}{c}-0.095 \\
{[0.019]^{\star *}}\end{array}$ & $\begin{array}{c}-0.06 \\
{[0.020]^{\star *}}\end{array}$ & $\begin{array}{c}-0.116 \\
{[0.020]^{\star *}}\end{array}$ & Early Morning & 0.288 & $\begin{array}{c}-0.105 \\
{[0.033]^{\star \star}}\end{array}$ & $\begin{array}{c}-0.118 \\
{[0.037]^{\star *}}\end{array}$ & $\begin{array}{c}-0.099 \\
{[0.036]^{\star *}}\end{array}$ \\
\hline Partial Rear Impact & 0.319 & $\begin{array}{c}-0.123 \\
{[0.033]^{\star *}}\end{array}$ & $\begin{array}{c}-0.162 \\
{[0.038]^{\star *}}\end{array}$ & $\begin{array}{c}-0.124 \\
{[0.033]^{\star \star}}\end{array}$ & Weekday & 0.256 & $\begin{array}{c}-0.136 \\
{[0.009]^{\star *}}\end{array}$ & $\begin{array}{c}-0.138 \\
{[0.010]^{\star *}}\end{array}$ & $\begin{array}{c}-0.113 \\
{[0.009]^{\star *}}\end{array}$ \\
\hline Rear Impact & 0.296 & $\begin{array}{c}-0.088 \\
{[0.037]^{\star}}\end{array}$ & $\begin{array}{c}-0.133 \\
{[0.043]^{\star *}}\end{array}$ & $\begin{array}{c}-0.084 \\
{[0.039]^{\star}}\end{array}$ & Weekend & 0.225 & $\begin{array}{c}-0.124 \\
{[0.011]^{\star *}}\end{array}$ & $\begin{array}{c}-0.122 \\
{[0.012]^{\star \star}}\end{array}$ & $\begin{array}{c}-0.099 \\
{[0.012]^{\star *}}\end{array}$ \\
\hline No Collision & 0.347 & $\begin{array}{c}-0.232 \\
{[0.027]^{\star *}}\end{array}$ & $\begin{array}{c}-0.205 \\
{[0.030]^{\star *}}\end{array}$ & $\begin{array}{c}-0.158 \\
{[0.029]^{\star *}}\end{array}$ & In Car & 0.263 & $\begin{array}{c}-0.125 \\
{[0.009]^{\star *}}\end{array}$ & $\begin{array}{c}-0.133 \\
{[0.010]^{\star *}}\end{array}$ & $\begin{array}{c}-0.101 \\
{[0.009]^{* *}}\end{array}$ \\
\hline Crash Year: & & & & & In Minivan & 0.182 & -0.115 & -0.157 & -0.125 \\
\hline Pre-1993 & 0.260 & $\begin{array}{c}-0.107 \\
{[0.011]^{\star *}}\end{array}$ & $\begin{array}{c}-0.106 \\
{[0.014]^{\star \star}}\end{array}$ & $\begin{array}{c}-0.091 \\
{[0.011]^{\star \star}}\end{array}$ & In SUV & 0.174 & $\begin{array}{c}{[0.023]^{* *}} \\
-0.213\end{array}$ & $\begin{array}{c}{[0.024]^{\star \star}} \\
-0.198\end{array}$ & $\begin{array}{c}{[0.026]^{* *}} \\
-0.157\end{array}$ \\
\hline $1994-1998$ & 0.235 & $\begin{array}{c}-0.128 \\
{[0.014]^{* *}}\end{array}$ & $\begin{array}{c}-0.127 \\
{[0.014]^{\star *}}\end{array}$ & $\begin{array}{c}-0.1 \\
{[0.014]^{* *}}\end{array}$ & $\begin{array}{l}\text { Properly Used Seat } \\
\text { Belts and Child }\end{array}$ & 0.242 & $\begin{array}{c}{[0.021]^{* *}} \\
-0.142\end{array}$ & $\begin{array}{c}{[0.021]^{* *}} \\
-0.136\end{array}$ & $\begin{array}{c}{[0.026]^{\star *}} \\
-0.11\end{array}$ \\
\hline $1999-2003$ & 0.216 & $\begin{array}{c}-0.166 \\
{[0.013]^{\star *}}\end{array}$ & $\begin{array}{c}-0.178 \\
{[0.013]^{\star *}}\end{array}$ & $\begin{array}{c}-0.153 \\
{[0.015]^{\star *}}\end{array}$ & $\begin{array}{l}\text { Seats } \\
\text { Age }=2\end{array}$ & 0.255 & $\begin{array}{c}{[0.007]^{* *}} \\
-0.131\end{array}$ & $\begin{array}{c}{[0.008]^{* *}} \\
-0.135\end{array}$ & $\begin{array}{c}{[0.007]^{* *}} \\
-0.101\end{array}$ \\
\hline Model Year: & & & & & & & {$[0.012]^{\star *}$} & {$[0.022]^{* *}$} & {$[0.019]^{* *}$} \\
\hline Pre-1993 & 0.254 & $\begin{array}{c}-0.12 \\
{[0.008]^{* *}}\end{array}$ & $\begin{array}{c}-0.113 \\
{[0.009]^{\star *}}\end{array}$ & $\begin{array}{c}-0.094 \\
{[0.008]^{\star *}}\end{array}$ & Age $=3$ & 0.251 & $\begin{array}{c}-0.127 \\
{[0.014]^{\star *}}\end{array}$ & $\begin{array}{c}-0.134 \\
{[0.019]^{\star *}}\end{array}$ & $\begin{array}{c}-0.127 \\
{[0.017]^{* *}}\end{array}$ \\
\hline $1994-1998$ & 0.211 & $\begin{array}{c}-0.153 \\
{[0.016]^{\star *}}\end{array}$ & $\begin{array}{c}-0.19 \\
{[0.016]^{\star \star}}\end{array}$ & $\begin{array}{c}-0.172 \\
{[0.020]^{\star *}}\end{array}$ & Age $=4$ & 0.239 & $\begin{array}{c}-0.144 \\
{[0.017]^{\star *}}\end{array}$ & $\begin{array}{c}-0.166 \\
{[0.016]^{\star \star}}\end{array}$ & $\begin{array}{c}-0.116 \\
{[0.015]^{\star *}}\end{array}$ \\
\hline $1999-2003$ & 0.187 & $\begin{array}{c}-0.212 \\
{[0.025]^{\star \star}}\end{array}$ & $\begin{array}{c}-0.196 \\
{[0.026]^{\star \star}}\end{array}$ & $\begin{array}{c}-0.175 \\
{[0.031]^{\star \star}}\end{array}$ & Age $=5$ & 0.237 & $\begin{array}{c}-0.114 \\
{[0.026]^{\star *}}\end{array}$ & $\begin{array}{c}-0.117 \\
{[0.016]^{\star *}}\end{array}$ & $\begin{array}{c}-0.107 \\
{[0.016]^{\star *}}\end{array}$ \\
\hline Speed Limit 55 mph & 0.245 & $\begin{array}{c}-0.133 \\
{[0.008]^{\star *}}\end{array}$ & $\begin{array}{c}-0.13 \\
{[0.008]^{\star *}}\end{array}$ & $\begin{array}{c}-0.098 \\
{[0.008]^{\star *}}\end{array}$ & Age $=6$ & 0.234 & $\begin{array}{c}-0.137 \\
{[0.046]^{\star *}}\end{array}$ & $\begin{array}{c}-0.118 \\
{[0.017]^{\star *}}\end{array}$ & $\begin{array}{c}-0.099 \\
{[0.017]^{\star *}}\end{array}$ \\
\hline
\end{tabular}


Notes to table 4: The reported coefficients are from regressions in which the dependent variable is an indicator variable equal to one if the child dies in a crash and zero otherwise. The top row represents the baseline estimates for the full sample, including the full set of covariates including dummies for year, model year, and the number of people in the crash, i.e. the same set of covariates presented in column (5) of Table 3. Each row reflects a different subset of the overall data set. The omitted

restraint category is "no restraint." See appendix for precise rules for inclusion in the sample. All reported regressions are linear probability models as described in the

text. Also reported is the mean fatality rate in the sub-sample for unrestrained 2-6 year old passengers. 
Table 5: Impact of Child Restraints on Probability of Fatality with Sample Selection Correction

\begin{tabular}{|c|c|c|c|c|c|}
\hline & \multicolumn{5}{|c|}{ Dependent Variable $=1$ if Fatal Injury, 0 Otherwise } \\
\hline & $(1)$ & (2) & (3) & $(4)$ & $(5)$ \\
\hline \multirow[t]{2}{*}{ Child Seat } & -0.055 & -0.056 & -0.059 & -0.05 & -0.054 \\
\hline & {$[0.006]^{* *}$} & {$[0.006]^{* *}$} & {$[0.007]^{\star *}$} & {$[0.007]^{* *}$} & {$[0.007]^{* *}$} \\
\hline \multirow[t]{2}{*}{ Lap and Should Belt } & -0.057 & -0.059 & -0.059 & -0.05 & -0.052 \\
\hline & {$[0.006]^{* *}$} & {$[0.006]^{\star *}$} & {$[0.007]^{\star \star}$} & {$[0.007]^{* *}$} & {$[0.007]^{* *}$} \\
\hline \multirow[t]{2}{*}{ Lap-Only Belt } & -0.067 & -0.064 & -0.053 & -0.044 & -0.046 \\
\hline & {$[0.006]^{* *}$} & {$[0.006]^{* *}$} & {$[0.007]^{\star *}$} & {$[0.007]^{* *}$} & {$[0.007]^{* *}$} \\
\hline $\begin{array}{l}\text { Controls included in } \\
\text { regression, but not } \\
\text { reported in table }\end{array}$ & & $\begin{array}{l}\text { age, seat } \\
\text { position }\end{array}$ & $\begin{array}{l}\text { age, impact, } \\
\text { seat position, } \\
\text { year of crash, } \\
\text { model year }\end{array}$ & $\begin{array}{l}\text { age, impact, } \\
\text { seat position } \\
\text { year of crash, } \\
\text { model year, } \\
\text { others }\end{array}$ & $\begin{array}{l}\text { age, impact, } \\
\text { seat position, } \\
\text { year of crash, } \\
\text { model year, } \\
\text { number in } \\
\text { crash, other } \\
\text { controls }\end{array}$ \\
\hline Observations & 12548 & 12548 & 12548 & 12548 & 12548 \\
\hline R-squared & 0.01 & 0.02 & 0.1 & 0.11 & 0.12 \\
\hline
\end{tabular}

Notes: Dependent variable is an indicator equal to one if the child dies in the crash. The omitted restraint category is "no restraint." As a correction for sample selection, only two-car crashes in which at least one person dies in the other vehicle are included in the sample. Otherwise, the structure of the table is identical to that of Table 3 . Standard errors are in parentheses. 
Table 6: Injury Severity and Child Restraints

\begin{tabular}{|c|c|c|c|c|}
\hline \multirow[b]{2}{*}{ Independent Variable } & \multicolumn{4}{|c|}{ Without Sample Selection Correction } \\
\hline & No Restraint & Child Seat & $\begin{array}{c}\text { Lap and } \\
\text { Shoulder Belt }\end{array}$ & Lap-Only Belt \\
\hline & $(1)$ & $(2)$ & (3) & (4) \\
\hline \multirow[t]{2}{*}{ Fatal } & 0.293 & -0.132 & -0.132 & -0.108 \\
\hline & & {$[0.007]^{* *}$} & {$[0.008]^{\star *}$} & {$[0.007]^{* *}$} \\
\hline \multirow[t]{2}{*}{ Incapacitating } & 0.314 & -0.099 & -0.091 & -0.079 \\
\hline & & {$[0.008]^{\star *}$} & {$[0.008]^{* *}$} & {$[0.008]^{* *}$} \\
\hline \multirow[t]{2}{*}{ Non-incapacitating } & 0.220 & 0.041 & 0.054 & 0.045 \\
\hline & & {$[0.007]^{* *}$} & {$[0.008]^{\star *}$} & {$[0.008]^{\star *}$} \\
\hline \multirow[t]{2}{*}{ Possible Injury } & 0.089 & 0.062 & 0.058 & 0.051 \\
\hline & & {$[0.006]^{* *}$} & {$[0.006]^{* *}$} & {$[0.006]^{* *}$} \\
\hline \multirow[t]{3}{*}{ No Injury } & 0.084 & 0.128 & 0.112 & 0.092 \\
\hline & & {$[0.006]^{\star *}$} & {$[0.006]^{\star *}$} & {$[0.006]^{\star *}$} \\
\hline & \multicolumn{4}{|c|}{ With Sample Selection Correction } \\
\hline \multirow[t]{2}{*}{ Independent Variable } & No Restraint & Child Seat & $\begin{array}{c}\text { Lap and } \\
\text { Shoulder Belt }\end{array}$ & Lap-Only Belt \\
\hline & (1) & $(2)$ & (3) & (4) \\
\hline \multirow[t]{2}{*}{ Fatal } & 0.097 & -0.054 & -0.052 & -0.046 \\
\hline & & {$[0.007]^{* *}$} & {$[0.007]^{* *}$} & {$[0.007]^{\star *}$} \\
\hline \multirow[t]{2}{*}{ Incapacitating } & 0.301 & -0.133 & -0.122 & -0.106 \\
\hline & & {$[0.013]^{\star *}$} & {$[0.013]^{\star *}$} & {$[0.012]^{\star *}$} \\
\hline \multirow[t]{2}{*}{ Non-incapacitating } & 0.273 & -0.015 & -0.004 & 0.017 \\
\hline & & {$[0.014]$} & [0.014] & {$[0.013]$} \\
\hline \multirow[t]{2}{*}{ Possible Injury } & 0.138 & 0.045 & 0.040 & 0.035 \\
\hline & & {$[0.012]^{\star *}$} & {$[0.012]^{\star *}$} & {$[0.012]^{\star *}$} \\
\hline \multirow[t]{2}{*}{ No Injury } & 0.191 & 0.157 & 0.138 & 0.100 \\
\hline & & {$[0.013]^{\star *}$} & {$[0.013]^{\star *}$} & {$[0.013]^{\star *}$} \\
\hline
\end{tabular}

Notes: Values in columns 2-4 are coefficient estimates and standard errors from regressions with indicator variables for injuries sustained in crashes. The specifications include the full set of controls in column (5) of Table 3. See appendix for precise rules for inclusion in the sample. All reported regressions are linear probability models as described in the text. Each row corresponds to a different, mutually exclusive injury category. Column (1) reports the sample average among 2 - 6 year olds who are unrestrained. The top panel includes all 2-6 year olds in crashes with at least one fatality; the bottom panel corrects for sample selection by limiting the sample to two-vehicle crashes in which there is at least one fatality in the other vehicle. 
Table 7: Differential Impact of Seat Position on the Probability of Death for Children and Adults

\begin{tabular}{|c|c|c|c|c|}
\hline & \multicolumn{2}{|c|}{ No Sample Selection Correction } & \multicolumn{2}{|c|}{ With Sample Selection Correction } \\
\hline & Ages $2-6$ & Ages 16 and up & Ages $2-6$ & Ages 16 and up \\
\hline \multirow[t]{2}{*}{ child seat } & -0.132 & - & -0.054 & - \\
\hline & {$[0.007]^{\star *}$} & - & {$[0.007]^{* *}$} & - \\
\hline \multirow[t]{2}{*}{ lap and shoulder belt } & -0.132 & -0.235 & -0.052 & -0.123 \\
\hline & {$[0.008]^{\star *}$} & {$[0.001]^{* *}$} & {$[0.007]^{\star *}$} & {$[0.002]^{\star *}$} \\
\hline \multirow[t]{2}{*}{ lap-only belt } & -0.108 & -0.179 & -0.046 & -0.094 \\
\hline & {$[0.007]^{\star *}$} & {$[0.003]^{\star *}$} & {$[0.007]^{\star *}$} & {$[0.003]^{\star *}$} \\
\hline \multicolumn{5}{|l|}{ person seated in: } \\
\hline \multirow[t]{2}{*}{ front } & 0.091 & 0.12 & 0.027 & 0.069 \\
\hline & {$[0.007]^{\star *}$} & {$[0.003]^{\star *}$} & {$[0.007]^{\star *}$} & {$[0.006]^{\star *}$} \\
\hline \multirow[t]{2}{*}{ back left } & 0.047 & 0.063 & 0.019 & 0.028 \\
\hline & {$[0.007]^{* *}$} & {$[0.004]^{\star *}$} & {$[0.007]^{\star *}$} & {$[0.006]^{* *}$} \\
\hline \multirow[t]{2}{*}{ back middle } & 0 & 0 & 0 & 0 \\
\hline & {$[0.000]$} & {$[0.000]$} & {$[0.000]$} & {$[0.000]$} \\
\hline \multirow[t]{2}{*}{ back right } & 0.039 & 0.031 & 0.011 & 0.017 \\
\hline & {$[0.007]^{\star *}$} & {$[0.004]^{\star *}$} & {$[0.007]$} & {$[0.006]^{\star *}$} \\
\hline \multirow[t]{2}{*}{ other back } & 0.027 & 0.074 & 0.021 & 0.056 \\
\hline & {$[0.014]$} & {$[0.009]^{\star *}$} & {$[0.017]$} & {$[0.018]^{\star *}$} \\
\hline covariates & $\begin{array}{l}\text { year, model year, } \\
\text { number in crash, } \\
\text { full set of controls }\end{array}$ & $\begin{array}{l}\text { year, model year, } \\
\text { number in crash, } \\
\text { full set of controls }\end{array}$ & $\begin{array}{l}\text { year, model year, } \\
\text { number in crash, } \\
\text { full set of controls }\end{array}$ & $\begin{array}{l}\text { year, model year, } \\
\text { number in crash, } \\
\text { full set of controls }\end{array}$ \\
\hline Observations & 37635 & 1121038 & 12548 & 312811 \\
\hline R-squared & 0.11 & 0.28 & 0.12 & 0.25 \\
\hline
\end{tabular}

Notes: The dependent variable in all specifications is an indicator equal to one if the occupant dies. Columns 1 and 3 limit the sample to occupants aged 2-6; columns 2 and 4 are for occupants aged 16 and up. The data are from the Fatality Analysis Reporting System (FARS) for the years 1975-2003. See appendix for precise rules for inclusion in the sample. All reported regressions are linear probability models as described in the text. The restraint type variables--lap and shoulder belt or lap or shoulder belt--are relative to no restraint use. The seating position variables, such as front or back left, are relative to the middle seat in the back. The full set of covariates used in column 5 of Table 3 are included in these specifications, but not reported in the table.

Columns 1 and 2 use all crashes; columns 3 and 4 correct for sample selection by limiting the sample to twovehicle crashes in which someone dies in the other vehicle. 


\section{DATA APPENDIX}

All data used in this study are taken from the Fatality Analysis Reporting System (FARS) collected by the National Highway Traffic Safety Administration (NHTSA). FARS provides detailed data on all occupants and non-motorists involved in motor-vehicle accidents resulting in at least one fatality. Crashes from calendar years 1975-2003 were included in the analysis. Programs and log files are available on request from the author.

The following exclusions were made from the dataset:

1) Any crash in which the only deaths were to non-motorists were excluded from the sample.

2) All non-motorists, large trucks, motorcyclists, and other non-standard vehicles (drop if body_typ $>39$ | body_typ==12 | body_typ==13 | (body_typ>20 \& body_typ<30) | body_typ $==32$ | body_typ==33).

3) All vehicles with model years prior to 1970 (before 1998, mod_year<70; during and after 1998, mod_year<1970).

4) Observations were dropped when the injury severity was unknown, when an occupant dies prior to the accident, or when injury severity was missing (inj_sev $>4$ ).

5) Observations were dropped when the restraint use was unknown, a motorcycle or bicycle helmet was used, or a helmet was used improperly (the commands depend upon the years: (rest_use $>4$ \& year $>=1991$ \& year $<=1993)$, (((rest_use $>=5 \&$ rest_use $<=8)$ | rest_use $>=15$ ) $\&$ year $>=1994$ ), and (rest_use $>4 \&$ year $<=1990)$ ).

6) Observations were dropped if the person was not classified as sitting in the first three rows of the vehicle (the commands depend upon the years: (seat_pos>39\&year>1981) and (year<1982\&seat_pos $>=13$ )).

7) In the regressions, any observation with missing data for any of the covariates (except for the vehicle's weight) was excluded.

8) For the great majority of the analysis, the sample was restricted to children between the ages of 2 and 6 (age $>1 \&$ age $<7$ ).

Variable Definitions and Other Notes:

Lap-Only Belt: A dummy equal to one if the restraint used was either a lap belt or a shoulder belt, not both ((rest_use==2|rest_use==1) for 1991-2003, (man_rest==1|man_rest==2)).

Lap and Shoulder Belt: A dummy equal to one if the restraint used was a lap and shoulder belt, not one or the other ((rest_use==3) for 1991-2003, (man_rest)==3 for 1975-1990).

Child Seat: A dummy equal to one if the restraint used was a child seat ((rest_use==4) for 19912003, (man_rest)==4 for 1975-1990). Unfortunately, the data do not give a breakdown of the type of child seat—e.g. rear-facing infant seat.

Beginning in 1994, NHTSA began differentiating between properly and improperly used restraints. Thus, after 1993, observations with rest_use $==14$ (improperly used child seat) were classified as using a child seat. Rest_use $==13$ indicates that it was an improperly used seat belt. However, because we have two different dummies for seat belt use, we compared these values to properly used seat belt values for the same make and model vehicle to assign these values to either Lap and Shoulder Belt or Lap-Only Belt.

The dummy variables front, back left, back middle, back right, and back other refer to the position in the car where the person was seated (front: seat_pos $<20$ after 1981, ((seat_pos $<4 \&$ seat_pos $>0) \mid$ seat_pos==10) before 1982) (back left: (seat_pos==21|seat_pos==31) 
after 1981, (seat_pos==4|seat_pos==7) before 1982) (back middle:

(seat_pos $==22$ |seat_pos $==32$ ) after 1981, (seat_pos $==5 \mid$ seat_pos $==8$ ) before 1982) (back right:

(seat_pos $==23 \mid$ seat_pos $==33$ ) after 1981, (seat_pos $==6 \mid$ seat_pos $==9$ ) before 1982) (back other:

(seat_pos $==28 \mid$ seat_pos $==29 \mid$ seat_pos $==38 \mid$ seat_pos==39) after 1981,

(seat_pos==11|seat_pos==12) before 1982). Someone would be classified as back left if she

were seated on the left side of the vehicle, behind the driver, in either the second or third row of seats (observations in the $4^{\text {th }}$ row or further back were dropped as noted above).

The impact of crash variables describe where the principle point of impact of the crash occurred on the car. The options include front (impact2==12), partial front

(impact2==1|impact2==2|impact==11|impact2==10), side (Right: impact2==3, Left:

impact $2==9$ ), partial rear (impact $2==7 \mid$ impact $2==8 \mid$ impact $2==5 \mid$ impact $2==4$ ), and rear (impact2==6).

Other dummy variables indicate whether the driver was male (sex==1), if she was wearing a seat belt, if it was a single car accident (ve_forms==1 after 1981, vehicles==1 before 1982), if it was a two car accident (ve_forms==2, vehicles==2 before 1982), the weight of the vehicle (vin_wgt), if the weight of the vehicle was missing (when this happened, the weight of the vehicle was replace with a zero and the dummy indicating missing weight was set to one) (vin_wgt==9999 and make vehicle weight missing $=1$ ), if the speed limit on the road where the crash occurred was less than or equal to 55 miles per hour (sp_limit $<=55 \&$ sp_limit $>0$ ) .

Number in Crash: This variable is the number of motor vehicle occupants involved in the crash.

The dummies that indicate the time of day (Daytime, Evening, and Early Morning) divide the day into three periods: Daytime is set to 1 if the crash occurs between 6 am and 7:59 pm, Evening is set to 1 if the crash occurs between $8 \mathrm{pm}$ and 12:59 am, Early Morning is set to 1 if the crash occurs between 1 am and 5:59 am.

Injury severity:Incapacitating Injury (inj_sev==3), Non-Incapacitating Injury (inj_sev==2), Possible Injury (inj_sev==1), and No Injury (inj_sev==0).

Car, Minivan, and SUV are dummies indicating the type of vehicle the observation was riding in. The automobile was classified as car if (body_typ $>=1$ \& body_typ $<=9$ before 1982, ((body_typ $>=1 \&$ body_typ<=11)|body_typ==67) between 1982 and 1990, and body_typ $>=1 \&$ body_typ $<=11$ after 1990). The automobile was classified as a minivan if the year was after 1990 and body_typ $==20$. The vehicle was classified as an SUV if the year was after 1990 and body_typ $>13 \&$ body_typ $<16$.

A dummy called rural was created equal to one if road_fnc $<10$ (except for between and including 1981 and 1986 when road_fnc was between 6 and 8 for rural roads).

Weekend was a dummy created equal to one if day_week==1 or day_week==7. Weekday was created equal to one if day_week $>=2$ \& day_week $<=6$.

For the sample selection correction, we created a dummy variable equal to one if someone died in another vehicle involved in the crash. 


\section{$\underline{\text { References }}$}

Braver, E.R., S. A. Ferguson, M..A. Greene, and A.K. Lund, 1997, "Reductions in Deaths in Frontal Crashes among Right Front Passengers in Vehicles Equipped with Passenger Air Bags,” JAMA 278:(17, Nov. 5):1437-1439.

Children’s Safety Network, 1996, “Childhood Injury: Cost and Prevention Facts,” Landover, MD: Children’s Safety Network, Economics and Insurance Resource Center.

Cohen, Alma, and Rajeev Dehejia, 2004, "The Effect of Automobile Insurance and Accident Liability Laws on Traffic Fatalities,” Journal of Law and Economics 47(2): 357-393.

Doyle, Joseph, and Steven Levitt, 2005, “Evaluating the Effectiveness of Child Safety Seats and Seat Belts for Injury Prevention in Motor Vehicle Crashes,” unpublished manuscript.

Dubner, Stephen, and Steven Levitt, 2005, “Do Car Seats Work?” New York Times Sunday Magazine, July 11.

Durbin, Dennis, Michael Elliot, and Flaura Winston, 2003, "Belt-Positioning Booster Seats and Reduction in Risk of Injury among Children in Vehicle Crashes," JAMA 289(21): 2835-2840.

Evans, L., 1986, “The Effectiveness of Safety Belts in Preventing Fatalities,” Accident Analysis and Prevention 18:229-241.

Glassbrenner, Donna, 2003, “Child Restraint Use in 2002 - Overall Results,” NHTSA Research Note, DOT HS 809 555, February.

Grabowski, David, and Michael Morrisey, 2004, “Gasoline Prices and Motor Vehicle Fatalities,” Journal of Policy Analysis and Management 23(3): 575-93.

Hertz, Ellen, 1996, “Revised Estimates of Child Restraint Effectiveness,” NHTSA Research Note, December.

Insurance Insittute for Highway Safety, 2004, “Child Restraint, Belt Laws as of July 2004,” as posted on www.highwaysafety.org/safety_facts/state_laws/restrain.htm.

Kahane, Charles, 1986, An Evaluation of Child Passenger Safety: The Effectiveness and Benefits of Safety Seats, Washington, DC: National Highway Traffic Safety Administration Report Number DOT HS 806890.

Kahane, Charles, 2004, “Lives Saved by the Federal Motor Vehicle Safety Standards and Other Vehicle Safety Technologies, 1960-2002 - Passenger Cars and Light Trucks - With a Review of 19 FMVSS and their Effectiveness in Reducing Fatalities, Injuries, and Crashes,” NHTSA Technical Report, DOT HS 809 833, October. 
Lave, Charles, and Patrick Elias, 1997, "Resource Allocation in Public Policy: The Effects of the 65-MPH Speed Limit,” Economic Inquiry 35(July): 614-620.

Levitt, Steven, and Jack Porter, 2001, "Estimating the Effect of Alcohol on Driver Risk using only Fatal Accident Statistics,” Review of Economics and Statistics , 83(40: 603-615.

Partyka, Susan, 1988, “Lives Saved by Child Restraints from 1982 through 1987,” DOT HS 807 371, December.

Peltzman, Sam, 1975, “The Effects of Automobile Safety Regulation,” Journal of Political Economy 83 (August): 677-725.

Ruhm, Christopher, 1996, “Alcohol Policies and Highway Vehicle Fatalities,” Journal of Health Economics 15(August): 435-454.

Saffer, Henry, and Michael Grossman, 1987, "Drinking Age Laws and Highway Mortality Rates: Cause and Effect,” Economic Inquiry 25(July):403-417.

Starnes, Marc, 2005, “Lives Saved Calculations for Infants and Toddlers,” NCS Research Note, DOT HS 809778 (March).

Tarbet, Marcia J, 2004, “Cost and Weight Added by the Federal Motor Vehicle Safety Standards for Model Years 1968-2001 in Passenger Cars and Light Trucks,” DOT HS 809 834, December.

U.S. Department of Transportation, National Highway Traffic Safety Administration, 1996, “Observed Patterns of Misuse of Child Safety Seats,” Technology Transfer Series, Number 133 (September).

Winston, F. K., D. R. Durbin, M. Kallan, and E. Moll, 2000, “The Danger of Premature Graduation to Seat Belts for Young Children,” Pediatrics 105: 1179-1183. 